\title{
Ellipsis
}

2015

\section{Partners Against the Dark}

Cynthia M. Davidson

University of New Orleans

Follow this and additional works at: https://scholarworks.uno.edu/ellipsis

\section{Recommended Citation}

Davidson, Cynthia M. (2015) "Partners Against the Dark," Ellipsis: Vol. 42 , Article 22.

DOI: https://doi.org/10.46428/ejail.42.22

Available at: https://scholarworks.uno.edu/ellipsis/vol42/iss1/22

This Fiction is brought to you for free and open access by the Department of English and Foreign Languages at ScholarWorks@UNO. It has been accepted for inclusion in Ellipsis by an authorized editor of ScholarWorks@UNO.

For more information, please contact scholarworks@uno.edu. 


\title{
Partners Against the Dark
}

\author{
Cynthia Davidson
}

My name is Xylia Xavier Vincent Ignatius. I'm a woman who learned how to fight and then had reasons to do so. I also have a great support guy. I call him Sawyer. That's not his real name, of course. I have to protect him just like he protects me. This is how we got our start.

Xylia is my real name. I was the only child of a woman named Beverly, who died within an hour after my birth. My father, Vaughn, enlisted shortly after she died. He said he needed a place to take his anger. Though I heard about him from his parents, I don't remember meeting him. He was killed in action before I reached the age of seven. His father, Xavier, told me he was sorry I would now have to carry the darkness of my father's unresolved anger along with the loss of both of my parents. My other grandfather, Vincent, tried to teach me ways to release this darkness. His ways worked for a while.

My closest cousins are William, four months older than me, and Yvonne, five days younger. If anyone else had come along, they would have been the lucky Z, but Yvonne was the last. I think the alphabet thing came about because we lived between Adams Township and Zanesville on the western edge of the Appalachian Mountains. In the winter, it felt like darkness would seep into everything.

Shortly after I turned eleven, I had my first fight. Jeffery Tillman tried to kiss me. I punched him as hard as I could.

"I would say you hit like a girl, but that would be a compliment," he said. Then he laughed as he walked away.

I went to see Grandfather Vincent, and I told him what happened.

"Now you will learn to hit like a warrior who wants peace." His voice was measured and quiet as he continued. "But I am afraid you will not have as much peace as you would like."

From that day, we worked together on my skills. He started me off slow with balance exercises and stamina. Then we moved on to strength training. He had me hauling logs and chopping firewood. It didn't matter that we had no access to a gym or fancy equipment. He kept me busy flipping old tires and moving heavy equipment or motor parts in the family garage.

When I turned thirteen, he began teaching me how to use a staff. It was a straight wooden rod, as long as I was tall. We wrapped the last eight inches at either end with electrical tape to keep it from splintering while I practiced. 
"Once you perfect your skill with this staff," he said, "we will make one from hardwood. I will teach you how to treat it with beeswax and wrap the ends with leather so it will be less likely to break."

I worked hard that year. I learned everything I could about maintaining my balance, no matter how far I needed to reach. I perfected my ability to climb. First, it was just the trees in our woods; then I was climbing everything I couldfire escapes, outcrops, even the water tower in town. I also spent time with William learning the family trade, small engine repair, from his father.

One day Grandfather Vincent said, "Now, we need some meat for the table. You will prove your skill by bringing in what is needed with the staff."

I knew this was my test. I figured a couple rabbits would be a good start, so I headed out to where I knew there were several nests. When I got to what I thought was the proper location, I did what I'd been taught. I didn't always believe Grandfather Vincent's prayers, but I respected him enough to honor them as best I could.

I knelt on the leaves and laid the staff in front of me. I sank back on my heels and closed my eyes. "Ancestors of all," I spoke softly and clearly. "I ask this day that you bring the one who has chosen to give his life for my family." I stayed motionless with my eyes closed for what seemed an appropriate length of time. I was completely relaxed and completely ready. When I opened my eyes, I could feel his presence behind me. I could feel his breath on my neck. The only thing I thought was you are way too tall to be a rabbit.

The fluid movements that had become almost second nature to me seemed to happen in slow motion. As I rose from my heels, I picked up the staff and twisted around while bringing it crashing down. The blow snapped the buck's neck, and he dropped instantly. I quickly pulled a knife and slit his throat so the blood would leave as fast as death would come.

I made quick work of the cleaning that needed to happen in the field. He wasn't anything to post a picture about, only seven points on his antlers. I made a travois from several small saplings and hauled him down to the house.

Grandfather Vincent had seen me coming across the field and called William from next door. William only balked once when he realized it was me and what I had. Then he laughed and shook his head. "Did that with the stick, huh?" After a few steps toward me he added, "Remind me never to piss you off."

We made short work of skinning the buck. Once we had it hung, William headed back home. He was itching to share the story.

A few days later, Grandfather Vincent helped me to begin preparing a staff from Osage orange. The entire process took several months. He taught me the old way of heating the wood with rocks from a fire and then melting the beeswax into it. "It will help protect the wood from shattering and give it extended flexibility," he said. We practiced on several scrap pieces so I wouldn't 
burn the new staff. "When we complete yours," he said, "we'll wrap the ends in some leather from that young buck's hide you tanned."

When these things were finished, we held a small ceremony to present me officially with the new staff. The smile on his face let me know how proud he was of me. When he said goodnight to me that evening, it was for the last time.

$* * *$

The next couple of years I worked odd jobs as a mechanic. I hadn't forgotten the unknowable darkness, filled with anger, which seemed to breathe down my neck when I was a child. I had simply learned to ignore it. Before I turned twenty, William's parents moved to Pittsburgh for better job opportunities, and he went with them. When Yvonne married a slightly older guy named Mickey, they moved into the family house on the land. Shortly after that, I abandoned the old cabin and moved to a warehouse-style apartment in town.

I often saw Yvonne and Mickey at the local pub where I threw darts several nights a week. The night Yvonne came in wearing dark glasses, my life changed forever. It was as if that horrible darkness I had been ignoring and running from now had a name-Mickey.

Yvonne's black eye wasn't too bad in the dim light of the bar, but when we stepped into the ladies room, it was a whole different story.

"It was an accident," she said.

"What?" I asked, "He accidentally put his fist in your face?" The anger I had never understood as a child was now bubbling like hot lava under my skin.

"No. No," Yvonne said, speaking fast. "I was mad at him. I was yelling hysterically, and he couldn't get me to calm down."

"So slugging you worked better than wrapping you in his arms and holding you until the quiet came?" I shook my head in disgust. "I don't believe this. You never even let your older brothers get away with hitting you. Why are you making excuses for Mickey?"

Yvonne straightened her back as she spoke. "I am not making excuses. This was a crazy accident. It will never happen again." She turned and stormed out of the restroom before I could respond.

I vowed that night, if he ever hit her again, he would answer to me. When I joined them at our table a few minutes later, they acted like the happy couple I had always thought them to be. Mickey looked at me and then glanced away. I knew the truth, and he knew it. A few minutes later I made some excuse about having an early day and left.

Once home, I pulled out my staff and sat crouched on my heels like I had that day I killed the young buck. I tried to recall everything Grandfather Vincent 
had taught me. I focused on balancing my physical body and my spirit against what was making me reel emotionally. When I believed I could practice without smashing things in my home, I picked up the staff and in one fluid motion stood and began my workout. As I went through my old routine, I realized how much it was helping to keep me calm and centered. I knew I was going to be doing this every day until I determined what to do about Mickey.

The next day, after working at a garage for a friend, I went for what I figured would be a short hike. It turned into a climbing event. After challenging myself with the tallest trees I could find, I went back into town and took on the fire escapes. I was halfway up the four-story apartment building behind the fire station when a captain came out for a smoke break. I spotted him, but I didn't think anything of it. He finished his smoke and leaned against the building to watch me work my way back down. When I landed on the ground, he walked over.

"If you weren't so good at that I'd be giving you a citation." He smiled before sticking his hand out and adding, "I'm Sawyer." Xylia."

"Thanks," I said as I shook his hand, "for not giving me a citation. I'm

"There's a building at our training facility that might give you a better challenge." Sawyer continued smiling as he talked to me. "Of course, you'd have to apply to be a volunteer firefighter to use it."

I now understood his grin. "So what exactly does that include?"

"Come on in, and I'll give you a packet." Sawyer led the way through the back door of the station into his office. He pulled a small packet of papers from a file and clipped his business card to the front. "Call me when you're ready to go see the climbing wall."

"I will," I replied. "Thanks." I left through the front and stopped at the first public bench to sit and glance through the packet. I had never thought about volunteering for anything. I looked at the requirements and knew I could certainly qualify. Then I looked at the information about the training center with its workout facilities and twenty-five-foot climbing wall. I pulled out my phone and called Sawyer.

"This is Captain Thomas."

"Hi, Sawyer. It's Xylia. When do I start?"

$* * *$

Yvonne was excited for me when she found out I was becoming a volunteer firefighter. "I think it's something you'll really enjoy. Besides, you get to hang out with the best looking guys in town." 
I laughed as I remembered that Yvonne always had a fireman's calendar hanging in her office. "It's a great way to stay in shape," I replied. "I always enjoyed tending burn piles and brush fires on the land. This is just an extension of that."

Mickey's silence was now common. He hadn't spoken ten words to me since Yvonne's black eye. I hoped that meant he had a healthy fear of what I might do if he ever pulled a stunt like that again. It seems he did, but only for a month or so.

I didn't realize anything had happened, at first. She didn't have an obvious shiner like the last time. When I pulled out my darts to get them ready, she spoke up.

"Oh," Yvonne said. "I really don't feel like throwing tonight. I'm a little stiff. I must have sat wrong at work."

"All the more reason to get up and throw," I responded. I reached for her arm to help her stand, and she flinched. Yvonne had never flinched in her life. Even her big brothers couldn't make her flinch. When I looked at Mickey, he turned away to watch a game on the big screen. I turned back to Yvonne. "I want to see it."

She shook her head. "It really isn't a big deal," she said. "I was yelling at him about something stupid. When he reached for me, I stepped away and slipped. I landed against the counter. I just bruised my ribs. It's no big deal. I didn't want you to know because I knew you would turn it into something more."

When I didn't respond, she simply looked away to watch the game, too. I sat in silence for a few minutes before I went to the boards and threw darts by myself.

"Is there anything you're not good at?"

I turned around to see Sawyer smiling over his beer at me. If I had been in a better mood, I might have responded differently. "Tolerating my cousin's abusive husband is getting a little rough." I glanced toward Yvonne and Mickey seated across the room.

Sawyer glanced in their direction, and when he looked back at me I could see that he understood. "I don't have much tolerance for things like that either."

We didn't say anything else as I slowly put my darts away. I no longer trusted myself not to turn around and throw them at Mickey's back. "I think I'll just head home," I said. "I really don't want to sit here and watch them pretend."

Sawyer left the last of his beer on the rail. "Come on," he said, "I'll walk you home."

When we got outside, he lit a cigarette and started heading down the street.

I kept pace with him and asked, "How did you know I was walking?" 
He exhaled smoke as he answered. "I know your truck pretty well, and I didn't see it anywhere. I also know you only live about seven blocks from here."

"Why does she let him do that to her?" I hadn't really meant to ask the question aloud. It just slipped out.

"Probably some combination of fear and lack of self-worth." Sawyer replied without rancor or arrogance. He was talking as if he knew. "I've seen way too much of it in my time with the department. It's easy to recognize, especially when you grew up with it."

"But Yvonne didn't grow up with it," I said. "She was raised in a loving family. She had a huge extended family for support, too."

"It's not that easy," Sawyer said. "Even in big supportive families one can feel alone."

"I don't get it," I said. "We always watched out for each other, took care of each other."

"I bet you had someone special," Sawyer said. "Someone who took time just for you. Someone who taught you how to sew or climb maybe?"

I nodded. "My grandfather. He taught me everything I know about balance and climbing and..."

Sawyer nodded, too. "You had someone who specifically focused on you. Who did that for Yvonne?"

I shook my head. "I don't know. I was usually busy with Grandfather Vincent. I know her brothers always watched out for her, but they were focused on their own plans."

"We all need someone in our corner," Sawyer said. "If we have just one person who teaches us that we are valuable no matter what happens, we can make it through. If we always feel like just one of the crowd, that nobody would really miss us if we were gone, well, that's a bit harder."

"I understand what you're saying. But what do I do now? I mean, I just want to wallop him one, but that doesn't seem like the best solution."

Sawyer smiled again. "Probably not, at least not yet. Why don't you try spending some time with your cousin alone? Let her know you care. Let her know she's important. Maybe it'll help."

"Thanks, Sawyer." I stopped in front of the door that led up to my warehouse apartment.

Sawyer stuck out his hand. "Call me if you need to," he said. Then he smiled and added, "You can always use the punching bag at the station."

I nodded and then let myself in. When I turned back, Sawyer was already a block away. 
Over the next few weeks, I made it a point to have lunch with Yvonne a couple times. I even drove her into Columbus to shop at Easton Mall. I let her know, as best I could, that I was there for her if she needed anything, that I cared about her and her happiness.

"I know you do," Yvonne said. "It's just a bad time for Mickey. He's struggling at work, and they're talking about more layoffs. He doesn't like anyone helping, like we're some charity case or something. I try not to say anything when I know he's down."

"What do you do when you're down?" I asked.

"Oh, I just get through it." Yvonne smiled and turned away. Then she did what she always does, change the subject. "So, who was that nice looking older man you were talking to the other day?"

"Probably Captain Thomas," I replied.

"Captain?" she asked. "As in fire department?"

"Yes," I replied. "He's the one who suggested I volunteer when he saw me climbing fire escapes."

"Is he single?" she asked.

"Why?" I queried back. "Are you looking for husband number two?"

"For you," she replied. "I mean, he is a bit older but still."

I just shook my head and didn't respond.

$$
* * *
$$

Two weeks later she came in the bar with her dark glasses on again. She didn't even wait for me to ask. "Look, I know what you're going to say. I know. It's not right." Yvonne paused for a breath and then continued. "What am I supposed to do? I love him, and he's just going through a rough time. When I suggested we get some help-ka-pow."

I took a breath before I spoke. "I'm sorry this is happening to you." I knew this had to be her choice if it was going to work. "What do you want to do?"

Yvonne looked at me with wide eyes for a moment and then relaxed a bit. "I don't know. I can't leave him. Where would I go? I can't kill him, and I don't really want to. I want him to get help, but he won't."

I nodded, trying to convey understanding. I tried another question. "Is there anyone he would talk to about it? Anyone he considers a friend?"

Yvonne shook her head. "They're all drinking buddies," she said. "Most of them are too afraid of Mickey to think of telling him what to do. No. No, Xylia, this is up to us to figure out." 
It was my turn to shake my head. "No, Yvonne," I said. "I'll help you in any way I can to carry out whatever you decide to do, but you have to make the choice."

"Fine," Yvonne replied. "Just help me figure out what my choices are."

"Off the top of my head?" I asked. I began to recite the short list I had come up with. "One, stay with him and take whatever crap he is going to dish out."

Yvonne looked horrified at this.

"Two, leave him, in whatever form that takes. Throw him off the family land. Move to Timbuktu. Take a cruise to Alaska and don't come back. Three, kill him. Poison, hit man, hunting accident-however you can figure it out. Four, send him away. Get him a job on an offshore rig or in the Arctic Circle." I paused for a moment. "I'm still trying to come up with a Five."

Yvonne laughed, "Five's easy, kill me."

I was glad when she continued to laugh. I hated suicide watch. the door."

When she stopped laughing, I said, "Let me guess, Mickey just came in

She nodded and began to stare at her beer.

I stood up and leaned over to her. "Call me when you decide what we're doing." I didn't even acknowledge Mickey as I walked over to a table full of firefighting friends. I stayed long enough to finish my beer and then headed out the door to go home.

As I walked past the station, I saw Sawyer's truck, so I went in to see if he had a minute to talk. His door was open, but he was turned away, so I knocked on the frame.

He glanced back and waved me in to have a seat. "I would ask what's up," he said. "But the look on your face says your cousin has new bruises."

I nodded and sat in the chair across from his desk. I quickly recounted the conversation I had just finished with Yvonne. "If I believed it would help, I would just beat the crap out of him myself."

Sawyer laughed. "If I thought it would do any good, I'd help you. Problem is most guys like him get really good at taking a beating when they're kids. That's often why they're good at giving them."

"So what do I do?"

"My suggestion? Wait for her to decide and hope it doesn't get worse in the meantime."

It must have shown on my face because Sawyer was holding up his hands in defense before I even got the word out. "Worse?"

"Xylia, take it easy." He shook his head and waited a minute before continuing. "Yes, worse. It's common in domestic abuse situations for things to get really nasty before someone is willing to get out or get real help. I know that 
isn't what you want to hear, but you know me well enough to know I rarely sugar coat anything."

"Yeah," I said. "I also know you're rarely wrong."

$$
* * *
$$

When the call came across the scanner three days later, I ran to the station and jumped on a truck. I didn't think driving in a blind rage would be a good idea. It had been a very dry spring. The fire that started in the main house had quickly raced across the parched ground to burn two of the old cabins. The woods were fully ablaze, and flames were creeping up the back of the old garage. But we didn't figure that out until the first gas can blew.

I did my best to forget where I was and let my instincts take over. By the time the fire was under control, the property was a complete loss. I was numb with fatigue and fury.

We found Yvonne's badly burnt remains in what had been the kitchen. Sawyer had to carry me physically away from the scene. Thrown over his shoulder, I screamed and pounded on his back so hard that I think I cracked one of his ribs. When he pushed me back to the ground for the third time, he said, "If you get up again, I'll tie you to that truck." I must have believed him because I didn't get tied to the truck. At least, not that I remember.

In fact, the next thing I remember was standing fully clothed in the shower at the station. When I looked Sawyer in the eye, he nodded and walked away. It was probably an hour later when I stepped out of the locker room in sweats and a t-shirt, barefoot but coherent. Sawyer was sitting at the kitchen table with several of the other guys. When I sat down, the others left, and Sawyer slid a cup of cold coffee in front of me.

After a few swallows, I asked, "How long?"

"We were at the scene for five hours," Sawyer replied. "You were unresponsive for twenty minutes."

I nodded and then asked, "Can I kill him now?"

Sawyer nodded. "But you have to eat first." 